\title{
Legal Ideal of Pancasila on Legal Politic in the Formulation of Laws and Regulations
}

\author{
Syarif ${ }^{1}$, Suparno $^{2}$ \\ Universitas Borobudur Jakarta ${ }^{12}$ \\ \{syarifunborr@gmail.com ${ }^{1}$, suparno@borobudur.ac.id $\left.{ }^{2}\right\}$
}

\begin{abstract}
In social, national, and state life, Pancasila has four positions, namely the state philosophy, ideology, legal ideals (rechtsidee), and the source of all sources of Indonesian law. Since the reformation of Pancasila, it has been neglected in the life of society, nation, and state. One of the disadvantages of reforming Pancasila is the erosion of Pancasila as the ideal of law and the source of all sources of law in the national legal system, resulting in Pancasila no longer having binding power in the national legal system. This is because Pancasila as a legal ideal (rechtsidee) has not been completely used in legal politics in the formation of legislation. For this reason, the importance of legal politics in the formation of legislation makes Pancasila a legal ideal that is embodied as the source of all sources of law in Indonesia. As a rule of law, the ideals of Pancasila law must be placed as a foundation and direction in the legal politics of the formation of legislation in Indonesia.
\end{abstract}

Keywords: the legal ideal of Pancasila; legal politic; legislation formation

\section{Preliminary}

The reforms and demands for amendments to the 1945 Constitution are a series of initiatives carried out by the Indonesian nation in welcoming changes to a better future. One of the logical consequences of the momentum of reform is the amendment to the 1945 Constitution. As the state constitution, the 1945 Constitution is seen as no longer suitable to the needs of the Indonesian people. In fact, in several ways, the provisions in the 1945 Constitution become an obstacle to the progress of the nation. The reformation was chosen as an effort to get out of the various deadlocks in the social, political, legal, and economic systems facing Indonesia. Instead of bringing the Indonesian people towards the lofty ideals outlined by the founders of the state, the system in effect has plunged the people into a prolonged multidimensional crisis.

In this reform era, Pancasila seems to have no power to influence and guide the Indonesian people in the life of the nation and state. One of the disadvantages of reforming Pancasila is the erosion of Pancasila as the ideal of law and the source of all sources of law in the national legal system, resulting in Pancasila no longer having binding power in the national legal system. The reality of law that is far from the corridors of the basic norms of the country causes the material content of the law in several laws and implementation in Indonesia to not 
find a clear form as an impact of legal politics in the formation of legislation which often does not make Pancasila a legal ideal (rechtsidee).

At least, there are three reasons for the erosion of Pancasila as the source of all sources of law since the reforms to date, namely: resistance to the New Order, strengthening legal pluralism, and the existence of a legal reality that makes Pancasila only a symbol. As for the development of the national legal system, especially in the formation of post-reform legislation, it is inseparable from various obstacles, both internal and external. Obstacles that come from within include first, the culture of society which tends to be feudalistic and paternalistic, which causes the law to become elitist and corrupt. Second, there is no awareness of national and state politics (national politics) of state administrators, so that the law which is a result of a political process does not base on the national interest but only on the interests of certain groups or communities.

While the obstacles that come from outside are first, the influence of globalization brings other ideologies outside of Pancasila, thus affecting a complete understanding of Pancasila, and influencing the mindset of society. Second, there is foreign policy pressure from superpower countries, resulting in conflicts between national interests and foreign interests which greatly affect the development process of the national legal system through the formation of legislation.

The occurrence of this cannot be separated from the legal politics in effect today which tends to ignore Pancasila as a legal ideal (rechtsidee) which should be embodied as the source of all sources of law in Indonesia. The neglect of Pancasila as a legal ideal result in several laws that are far from the values of Pancasila as the foundation in the life of society, nation, and state.

Therefore, the importance of the ideals of Pancasila in the legal politics of the formation of post-reform legislation is because several laws have been submitted for judicial review to the Constitutional Court. After all, they are deemed to violate the constitution and are not following the ideals of Pancasila law. As it is known, the legislation proposed for legal review is a legal political product produced by the DPR and the Government.

Based on this background, the ideals of Pancasila law in legal politics in the formation of legislation are important. It is important to research more focused and deeply from the perspective of legal science in the form of the ideals of Pancasila law in the politics of law in the formation of legislation. Assessing the ideals of Pancasila law in the legal politics of the formation of legislation in Indonesia based on historical and philosophical perspectives.

\section{Research Problem}

Based on the background described above, the formulation of this research problem can be formulated as follows: What are the ideals of Pancasila law in the formulation of laws and regulations?

\section{Research Method}

The research method is the most important part of a study because this research method will be the direction and guidance for a study.[1] The type of legal research used in this research is normative legal research, namely research based on legal materials which focus on studying primary and secondary legal materials. 
The approach used is the historical approach (historical approach) and the legal political approach (legal policy approach). The historical approach by examining the background and development of the material under study.[1] The political-law approach, namely an approach that is carried out by examining and understanding the politics of law in the formation of legislation.

\section{Discussion}

Etymologically, the term political law is an Indonesian translation of the Dutch legal term rechtspolitiek, which is a form of two words recht and politiek. In the Indonesian dictionary, the word recht means law and in the Dutch dictionary written by Van der Tas, the word Politiek means beleid. The word belied itself in Indonesian means policy.[2] From this explanation, it can be said that legal politics in short means legal policy.

Padmo Wahjono defines legal politics as a basic policy that determines the direction, form, and content of the law to be formed.[3] This definition is still abstract and then completed, which says that law politics is the policy of state administrators regarding what is used as a criterion for punishing something. In this case, the policy may relate to the formation of laws, the application of the law, and its enforcement.[4]

According to Mahfud MD, legal politics is defined as a legal policy that will be or has been implemented by the government. This law politics includes law-making which consists of making and updating legal materials so that they can be adapted to the needs, and the implementation of existing legal provisions, including enforcement of institutional functions and fostering law enforcers.[5]

In the perspective of F. Sugeng Istanto, legal politics is part of legal science and can be divided into three groups, namely legal politics as a translation of Political Rechts, legal politics is not a translation of Political Rechts and legal politics which discusses public policy.[6] Meanwhile, Sunaryati Hartono, stated that political law is a tool or means and steps that can be used by the government to create the desired national legal system and with this national legal system the aspirations of the Indonesian people will be realized.[7]

The legal politics of one country is different from the legal politics of another country. This difference is due to differences in the historical background, world view, socio-cultural, and political will of each government. In other words, political law is local and particular (only applies to and from certain countries), not universal. However, it does not mean that the legal politics of a country ignores the reality and politics of international law.

Furthermore, Sunaryati Hartono stated that the factors that will determine legal politics are not solely determined by what we aspire to or depending on the will of lawmakers, practitioners, or mere theorists, but also determined by reality, as well as legal developments in other areas. -Other countries, as well as developments in international law. The difference in the legal politics of a certain country with other countries has led to what is known as the National Law Politics.[7] National legal politics are the basic policies that state administrators (Republic of Indonesia) aspire to. Five agendas are emphasized in the politics of national law, namely:[2]
a. Basic policy issues covering concept and layout
b. State administrators who form the basic policies
c. Legal materials include current, current, and applicable laws.
d. The process of law formation
e. Political objectives of national law. 
In connection with the formation of legislation, statutory politics is a subsystem of the law. Therefore, political legislation cannot be separated from legal politics. Legislative politics is defined as the policy or regarding the determination of the content or object of the formation of statutory regulations. Politics regarding the procedures for formation related to the legal system and legal instruments used in the formation of statutory regulations. The politics of law enforcement is related to the functions of governance in the field of law.

Internally, one of the main spheres of legal politics is the politics of law formation, both regarding the procedures and contents of laws and regulations, which are policies related to the creation, reform, and development of laws, including policies on the formation of laws, policies on the formation of jurisprudence laws, policies on unwritten regulations. The legislation primarily will reflect various thoughts and political policies of law.

Indonesia's national legal politics were first formally made by the founders of the Indonesian nation at the same time as the birth of the Republic of Indonesia on August 17, 1945, and the following day the 1945 Constitution was enacted on August 18, 1945, wherein the Preamble of the 1945 Constitution contained Pancasila which is a reflection of the diversity of cultures and customs of the nation in the unitary state of the Republic of Indonesia. Pancasila is the principle that guides and guides the formation of the 1945 Constitution, laws, and other regulations.

From a historical point of view, Pancasila as the basis of the state was first proposed by Ir. Soekarno at the trial of the Investigative Body for Preparatory Efforts for Indonesian Independence on June 1, 1945, at the time he discussed Pancasila as the basis of the state. Since then, Pancasila has also been used as the name of the basic philosophy of the state and the way of life of the Indonesian people, although there are several different sequences and formulas for this.

In its development, further, the position of Pancasila in the life of the nation and state is other than as the basis of the state, as the philosophy of the nation and the country of Indonesia, and as the ideology of the country, as well as the ideology or rechtsidee embodied in the position of Pancasila as a source of all legal resources.

According to Arief Hidayat, philosophically the Preamble of the 1945 Constitution is a mode of Vivendi (noble agreement) for the Indonesian people to live together in the bonds of one plural nation. The preamble to the 1945 Constitution can also be referred to as a certificate of birth, which contains a statement of independence (proclamation), self-identity, and steps to achieve the ideals of the nation and national goals. From a legal point of view, the Preamble of the 1945 Constitution which contains Pancasila is the basis for the state philosophy that gives birth to legal ideals (rechtsidee) and the basis for a separate legal system by the spirit of the Indonesian nation itself.[8]

The position of Pancasila as a legal ideal (rechtside) is a reflection of a fundamental reflection on the struggle to build a legal order based on the noble values of the Indonesian nation and idealized in the national legal system. The philosophical foundation formulated in the fourth paragraph of the Preamble to the 1945 Constitution is Pancasila which reflects the five main principles. [9]

The preamble to the 1945 Constitution and the Pancasila it contains constitute the principles of fundamental state principles of statutory norms and cannot be changed through the law unless changes are made to the Indonesian identity which was born in 1945 .

By making Pancasila the fundamental norm, the formation of law, its application, and implementation cannot be separated from the values of Pancasila.[10] The consequence is that Pancasila is positioned as a fundamental norm in the legal norm system which determines that the legal norms under it are formed following and not in conflict with Pancasila.[11] 
The goals of the Indonesian state are definitively contained in the fourth paragraph of the Preamble to the 1945 Constitution of the Republic of Indonesia, namely: Protect the entire nation and all spilled Indonesian blood; Promote the general welfare; To educate the nation's life;To participate in implementing world peace, based on freedom, eternal peace, and social justice.

The realization of this country's goals is the obligation of the Indonesian state as the highest organization of the Indonesian nation whose implementation must be based on the five principles of the state (Pancasila). Therefore, in every legal politics (policy) taken by state administrators in the effort to organize a state based on Pancasila law (including the formation of legislation), it must comply with the four principles of legal ideals (rechtsidee) of Indonesia (Pancasila), namely:[12]

a. Maintaining the integration of the nation and state both ideologically and territorially.

b. Realizing the sovereignty of the people (democracy) and the rule of law (nomocracy)

c. at once, as an inseparable whole.

d. Realizing general welfare and social justice for all Indonesian people.

e. Creating tolerance based on humanity and civilization in religious life.

Here it can be understood that Pancasila is the basic norm of the Indonesian state (grundnorm) and is also the ideal of Indonesian state law (rechtsidee) as a belief framework. According to Hamid Attamimi, Pancasila as a legal ideal (rechtsidee) will carry out its two functions which are constitutive and which are regulative towards the Indonesian legal norm system consistently and continuously. As a legal ideal (rechtsidee), Pancasila has three values, namely:[13]

a. The value of the policy, that is, the principles accepted as a proposition that is a little too much absolute. The basic values of Pancasila are divinity, humanity, unity, citizenship, and justice.

b. Instrumental values, that is, the general implementation of fundamental values, especially formed legal norms that are further crystallized in legislation.

c. Practical value, that is, the value that is implemented in the reality that comes from the basic value and instrumental value, so that the practical value is a tested stone whether the basic value and instrumental value lives in Indonesian society.

In connection with legal politics in the formation of legislation in Indonesia, there are 3 levels of the statutory political policy contained in the staatsidee or rechtsidee framework and paradigm, namely:

a. In a political system, the objective of Indonesian law is the establishment of a democratic constitutional state.

b. In the social and economic order, political law aims to achieve

c. social justice for all the people of Indonesia.

d. In a normative order, political law aims at upholding justice and truth in every aspect of public life.

These three objectives are at a national legal level which is based on and based on Pancasila and the 1945 Constitution. Therefore, by making Pancasila the guide for positive law in Indonesia, Pancasila is the source of all sources of law in Indonesia. According to Kirdi Dipoyudo, that as the basis of the state Pancasila is the source of state order and legal order, supreme power, the soul of the 1945 Constitution, and guidelines for interpreting it and for implementing it in statutory regulations.[14]

In the Dutch literature, statutory regulations are categorized as "wet in material zin" or laws in the material sense (broad), while "wet in formele zin" are laws in the formal sense. Laws in a material sense or commonly referred to as "algemeen verbidende voorschrift" are 
generally binding written legal regulations, including: "de supra-nationale algemeen verbidende voorschriften, wet, $A M V B$, de mineteriele verordeningen, de gemeentelike raadverordeningen, de provinciale verordeningen statent ".[15] In Indonesia, the forms of "wet in materile zin" have been established based on Law No. 12 of 2011 on the Establishment of Legislative Regulations, Article 7 paragraph (1), which describes the legal hierarchy in Indonesia, namely (1) Constitution 1945; (2) Law; (3) Government Regulations Substituting for Laws; (4) Government Regulation; (5) Presidential Regulation; (6) Regional Regulations.

The rules that are in the first order are the rules with the highest hierarchy so that the rules under them should not contradict those rules. Hans Kelsen states that the lower law must be grounded, sourced, and not contrary to the higher law. The nature of the conflict with this lower law resulted in the annulment of the law.[16] In the Law Number 12 of 2011 concerning the Formation of Legislative Regulations, Article 2 states that Pancasila is the source of all sources of state law. Thus, legal politics in the formation of legislation in Indonesia as national law must be based on the principles of protection, humanity, nationality, kinship, nationality, diversity, justice, equality in law and government, order and legal certainty, balance, harmony, and harmony.[17] The principles of forming this statutory regulation are a derivation of the noble values of Pancasila as a legal ideal (rechtsidee).

Based on the explanation above, the position of Pancasila as a legal ideal has an important role in the politics of law in the formation of legislation. Concerning the formation of a national legal system, including statutory regulations, it must pay attention to the basic values of the state contained in Pancasila, because these values constitute hopes, desires, and obligations. Value means something ideal, is something to aspire to, hope for, and become a necessity.

\section{Conclusion and Suggestion}

\section{1 Conclusion}

In the context of recognizing Indonesia as a rule of law, legal politics in the formation of laws and regulations must be implemented in an integrated, planned, and sustainable manner in the national legal system to guarantee the protection of the rights and obligations of every citizen. The most important thing is to make Pancasila a legal ideal in legal politics which is internalized in the formation of laws and regulations. In the establishment of laws and regulations, it is imperative to make Pancasila a legal ideal other than as a philosophical foundation and state ideology in the life of the nation and state of Indonesia.

\subsection{Suggestion}

It is hoped that in the future, legal politics for the formation of legislation can return to the nation's philosophy by making Pancasila a legal ideal (rechtsidee) and also as a guiding star that provides guidelines and guidance in all legislative activities, provides the content to each statutory regulation, as well as the framework which limits the space for the contents of the statutory regulations. Pancasila is apart from being a legal ideal, as well as a dynamic ideology that can develop according to the context of the era, but its basic philosophy must be permanent according to the intentions of the Founders of the State. 


\section{References}

[1] Fajar, Mukti.: Dualisme Penelitian Hukum Normatif \& Empiris. Cet. Pertama, Pustaka Pelajar, Yogyakarta, 2010.

[2] Syaukani, Imam dan A. Ahsin Thohari.: Dasar-Dasar Politik Hukum. Raja Grafindo Persada, Jakarta, 2015.

[3] Wahjono, Padmo.: Indonesia Negara Berdasatkan Atas Hukum. Cet. II. Ghalia Indonesia, Jakarta, 1986.

[4] Wahjono, Padmo.: Menyelisik Proses Terbentuknya Perundang-Undangan. Forum Keadilan, No. 29 April 1991.

[5] Mahfud M.D., Moh.: Politik Hukum di Indonesia. LP3ES, Jakarta, 1998.

[6] Latif, Abdul dan Hasbi Ali.: Politik Hukum. Sinar Grafika, Jakarta, 2010.

[7] Hartono, C.F.G Sunaryati.: Politik Hukum Menuju Suatu Sistem Hukum Nasional. Alumni, Bandung, 1991.

[8] Hidayat, Arief.: Negara Hukum Berwatak Pancasila. Article. Retrieved from https://mkri.id/public/content/infoumum/artikel/pdf/artikel_15_03_arief_hidayat.pdf

[9] Sidharta, Arief.: Refleksi Tentang Ilmu Hukum: Sebuah Penelitan tentang fundasi kefilsafatan dan sifat keilmuan Ilmu Hukum sebagai landasan pembangunan Ilmu Hukum Nasional Indonesia. Mandar Maju, Bandung, 1999.

[10] Attamimi, A. Hamid. S.: Peranan Keputusan Presiden Republik Indonesia Dalam Menyelenggarakan Pemerintahan Negara, Suatu Studi Analisis Mengenai Keputusan Presiden Yang Berfungsi Pengaturan Dalam Kurun Waktu Pelita I- Pelita IV. Disertasi. Program Doktor Fakultas Pasca Sarjana. Universitas Indonesia, Jakarta, 1990.

[11] Kaelan.: Negara Kebangsaan Pancasila: Kultural, Historis, Filosofis, Yuridis, dan Aktualisasinya. Paradigma, Yogyakarta, 2013.

[12] Mahfud M.D., Moh.: Membangun Politik Hukum Menegakkan Konstitusi. Pustaka LP3ES, Jakarta, 2006.

[13] Prasetyo, Teguh dan Arie Purnomosidi.: Membangun Hukum Pancasila. Nusa Media, Bandung, 2014.

[14] Dipoyudo, Kirdi.: Pancasila, Arti dan Pelaksanaannya. CSIS, Jakarta, 1984.

[15] Manan, Bagir.: Fungsi dan Materi Peraturan Perundang-undangan. Makalah, Jakarta 1994.

[16] Rasjidi, Lili dan I.B Wyasa Putra.: Hukum Sebagai Suatu Sistem. Remaja Rosdakarya, Bandung, 1993

[17] Undang-Undang Republik Indonesia Nomor 12 Tahun 2011 tentang Pembentukan Peraturan Perundang-Undangan 